\title{
EXPLORATION OF FINANCIAL MANAGEMENT OPERATION OF POLITICAL AND NON-POLITICAL STUDENT ORGANIZATION: A BASIS FOR PROPOSE POLICY DEVELOPMENT
}

\author{
Rowell Agliones Diaz, MBA ${ }^{1}$ \\ Clarizza Lustre De Leon, $\mathrm{MBA}^{2}$ \\ Edgelly Galvez Vitug, $\mathrm{MBA}^{3}$ \\ Lester No Linsangan, EdD ${ }^{4}$
}

\begin{abstract}
${ }^{1}$ Accounting Faculty, Nueva Ecija University of Science and Technology, Philippines, wellro0917@gmail.com ${ }^{2}$ Finance Faculty, Nueva Ecija University of Science and Technology, Philippines, clrzdeleon@yahoo.com ${ }^{3}$ Human Resource Faculty, Nueva Ecija University of Science and Technology, Philippines., edgellyvitug14@gmail.com ${ }^{4}$ OSOAD Head, Nueva Ecija University of Science and Technology, Philippines, neust.lester@gmail.com
\end{abstract}

\begin{abstract}
A strong financialtransaction is an important factor in organizational triumph and sustainability, and it is elucidated in the revised student handbook of the University that can be found on page 96 rules 1 to 5. This study assessed the registered students organizations' profile in terms of its type, registration, years of establishment, functions, and designations of student leaders and advisers. The financial practices or internal control system manages their organizational finances and the problems encountered by the student organizations and eventually proposed a manual of operation for students and youth organization's internal control system. This research used the descriptive design with the aid of questionnaire; data gathering through quota sampling from 57 student leaders and advisers of different student organizations of NEUST. Findings showed that most organizations had their constitution and by-laws but kept only as files and renewal requirements. Some provisions were not known to the officers, mostly were registered more than five years in operation; however, in terms of functions of officers and advisers, the results showed that some functions were not done by the officers who supposed to do it like the auditors who serve as treasurers also, the PRO as the record keeper and the presidents who handled finances and collections and as well as disbursements of funds. Generally, the organizations' financial activities were deemed to be "good", especially budgeting and cash receipt, due to the implementation of "no collection and no tuition fee policy". The researchers concluded that the absence of the proper internal control systems and manual of operation and lack of proper transfer of financial records from the previous sets of officers were the serious problems that should be addressed. Moreover, the student organizations' internal control system could still be improved if there is proper training and supervision in accounting operation.
\end{abstract}

Keywords: transparency, accounting, internal control system, financial management, disbursement, a student organization.

\section{Introduction}

The Nueva Ecija University of Science and Technology (NEUST) is one of the state universities and colleges that provide quality education in the region. One of the University's core values aside from nationalism, excellence, unity, and spirituality is the last but one of the most important elements as public officials, the transparency.

Transparency in terms of financial accountability in NEUST top management levels even in the student councils is needed to attain the university objectives. According to Jongbloed 
(2018), the basic theoretical notion underlying the growing interest in openness or transparency in higher education stems from an (economic) conception of higher education as an experience good. An experience good is a good or service whose quality can only be judged after consuming it. The importance of transparency has been proven on the study of Rafindadi and Olanrewaj (2019) where they found out that the organization financial information, governance structure activities, listing of officers and partnership were open and accessible to public scrutiny; that the organization regularly seek feedback on its activities from project beneficiaries as well as the stakeholders and there exist promotion of a high level of compliance with the organizational financial policies and procedures.

Today's role in teaching core values is essential to ensure the smooth working of the day-today mechanism by making people aware of the responsibility, spread awareness, and motivating the students' fraternity to seek a solution. In the same vein, the student organizations organized to serve as a voice of the student body and act as students' representatives to the University's officials. Khandpekar (2016) emphasized that "today when the world is increasingly becoming more and more of one island," education can address the need to teach the broad and modern outlook in Generation $\mathrm{Z}$ through education.

Whatever issues, problems, or most especially, the University's activities, they can directly tell and inform people through simple conversation and letters for approval. The student association or organization also seeks to prepare students to become future president, budget officer, accountants, cash custodian, and the will to protect students' funds and interests and to ensure that the student funds are used to secure its real purpose. In line with this, London School of Business and Finance defined financial management as strategic planning, organizing, directing, and controlling financial undertakings in an organization or an institute. It also includes applying management principles to an organization's financial assets while also playing an important part in fiscal management. In summary of this view, Harvard College Office of Student Life stated that, a stable financial system is an important factor in student organizations' effectiveness and survival. Strong fiscal management provides a structure that encourages organizations to work proactively to achieve their objectives and support their communities through financially sustainable activities and programs. However, Tom York argued that in most situations, the use of simple financial controls would have brought the conduct to light much earlier and severely hindered or even avoided subsequent losses.

The involvement of non-governmental organizations worldwide has drawn attention to the variation of foreign and domestic policies used to identify and oversee NGOs' role following the part of the government (Taylor, 2019). In NEUST, the political and non-political student organizations act as an independent body. The elected officers can enact the students' events and programs upon the supervision of the designated advisers and approval of the University's official most especially the president. However, in the last few years, there has been a mutual understanding that certain student organizations have deficiencies because some projects were accomplished, but there were no sufficient documents support it and no specific forms to be accomplished that is significant for turn-over of the projects and properties. Unfortunately, other students cannot avoid to speculate about what happened to the membership, and other fees they have paid. In the study conducted by Perlas et al. (2018), it was revealed that there could be no rule of law and no accountability without records. Records provide a reliable, legally verifiable source of evidence, decisions and actions. Needless to say, these encouraged the researchers to find out whether these speculations are true and if proven this study well, to provide solutions to solve and eliminate these problems, and to evade these things from happening once more; and most importantly to guide officers and advisers to improve the 
financial operations of the organization using the proposed training and manual of operations for the internal control system of the concerned officials of the political and non-political student organizations. In fact, one of the objectives of the Office of Student Organization Activities and Development written in the revised student handbook of NEUST is to develop an information system concerning students' organizations, activities, and development.

\section{Materials and Methods}

Using the descriptive research method, the study evaluated the 57 respondents that included 48 student leaders and nine advisers of the Political and No-political student organizations.There were two sources where the data gathered. First, the study utilized a modified questionnaire in gathering the data needed. The questionnaire has three parts. Part 1, dealt with the students' profile, organization type, legality of operation and function, designation of officers and advisers, and years of operation; Part II, called for a response on the organization's financial activities specifically budgeting, cash receipts, cash disbursements, and recordkeeping/bookkeeping, Part III of this questionnaire dealt with the problems encountered by student organizations about financial management. Another source of data was interview to deepen the understanding for the current situation. The quota sampling technique was used in this study. Officers (24 from present and 24 from previous) and nine (9) advisers of NEUST San Isidro Campus student organizations were the selected respondents. They provided firsthand knowledge of how the student organization is being managed financially. Using these, the researchers have retrieved 57 questionnaires.

Gathered data from the instrument were tallied and analyzed. Using the weighted mean, the typicality of responses were determined. The quota sampling technique was used in this study. Student leaders and advisers (current and previous) of the political and non-political organizations were the selected respondents. They have first-hand evidence as to how the association/organization is being managed financially. With this method, the researchers retrieved 57 questionnaires from various political and non-political student organizations of NEUST-San Isidro Campus.The financial practices or activities of the student organizations were classified using the Likert scale and was interpreted as follows:

For the Financial Management Practices as Internal Control System, Part II:

Table 1: Financial Management Practices

\begin{tabular}{lllll}
\hline Degree & \multicolumn{2}{c}{ Verbal Interpretation } & \multicolumn{2}{c}{ Scale } \\
\hline & & & & \\
5 & Always & A & 4.21 & 5.00 \\
4 & Often & O & 3.41 & 4.20 \\
3 & Sometimes & S & 2.61 & 3.40 \\
2 & Rarely & R & 1.81 & 2.60 \\
1 & Never & N & 1.00 & 1.80 \\
\hline
\end{tabular}

For the problems encountered in terms of financial management, Part III:

Table 2: Problems Encountered in terms of Financial Management

\begin{tabular}{clccc}
\hline Degree & \multicolumn{2}{c}{ Verbal Interpretation } & \multicolumn{2}{c}{ Scale } \\
\hline & & & 4.21 & 5.00 \\
4 & Every-time & ET & 3.41 & 4.20 \\
3 & Almost every time & AET & 2.61 & 3.40 \\
2 & Occasionally & O & 1.81 & 2.60
\end{tabular}


Statistical Treatment of Data. Frequencies and percentages were used and applied to define the student organizations' profile in terms of type or form, the legality of operations, and the officers' and advisers' designations and functions.

\section{Results and Discussion}

Table 3: Types of Organization

\begin{tabular}{|c|c|c|c|c|c|c|c|c|}
\hline $\begin{array}{l}\text { Types of } \\
\text { organization }\end{array}$ & & Office & & & & & sers & \\
\hline Political: & $\begin{array}{c}\text { Presen } \\
t\end{array}$ & Percentage & Past & $\begin{array}{c}\text { Percentag } \\
\text { e }\end{array}$ & $\begin{array}{c}\text { Ad } \\
\mathbf{v}\end{array}$ & $\begin{array}{c}\text { Percentag } \\
\text { e }\end{array}$ & $\begin{array}{c}\text { Tota } \\
1\end{array}$ & $\begin{array}{c}\text { Percentag } \\
\text { e }\end{array}$ \\
\hline $\begin{array}{l}\text { CSC } \\
\text { CMBT }\end{array}$ & 4 & $7 \%$ & 4 & $7 \%$ & 2 & $4 \%$ & 10 & $18 \%$ \\
\hline $\begin{array}{l}\text { Confederation } \\
\text { Non-political: }\end{array}$ & 6 & $11 \%$ & 6 & $11 \%$ & 2 & $4 \%$ & 14 & $25 \%$ \\
\hline YMA & 6 & $11 \%$ & 6 & $11 \%$ & 2 & $4 \%$ & 14 & $25 \%$ \\
\hline $\begin{array}{l}\text { SYBEE } \\
\text { Other non- } \\
\text { political }\end{array}$ & 6 & $11 \%$ & 6 & $11 \%$ & 2 & $2 \%$ & 14 & $\begin{array}{l}25 \% \\
9 \%\end{array}$ \\
\hline & 24 & $42 \%$ & 24 & $42 \%$ & 9 & $16 \%$ & 57 & $100 \%$ \\
\hline
\end{tabular}

Table 3 shows that most of the respondents are from Non-political student organizations, primarily academic-related student organizations. Out of 57 respondents, 24 or $42 \%$ were represented by two political student officers, 6 from previous and 6 from current CMBT Confederation and 4 from current and 4 from previous Campus Student Council (CSC) officers and 4 advisers of the Campus Student Council, 24 or $42 \%$ were from the department based organizations, and 6 or 11\% represents the Young Marketing Association (YMA) and another 6 , or $11 \%$ from Society of the Young Business Executives and Entrepreneurs (SYBEE) and 2 from other non-political organization.

Table 4: The Legality of Operation (Present officers)

\begin{tabular}{|c|c|c|c|c|}
\hline & Yes & Percentage & No & Percentage \\
\hline Existing constitution and by-laws & 24 & $100 \%$ & 0 & $0 \%$ \\
\hline $\begin{array}{l}\text { Approved plan/calendar of } \\
\text { activities }\end{array}$ & 19 & $79 \%$ & 5 & $21 \%$ \\
\hline Approval of members in by laws & 0 & $0 \%$ & 24 & $100 \%$ \\
\hline $\begin{array}{l}\text { Registration with a national } \\
\text { confederation and organizations }\end{array}$ & 6 & $25 \%$ & 18 & $75 \%$ \\
\hline Election of officers from members & 6 & $25 \%$ & 18 & $75 \%$ \\
\hline $\begin{array}{l}\text { Issuance of special order to } \\
\text { advisers }\end{array}$ & 24 & $100 \%$ & 0 & $0 \%$ \\
\hline
\end{tabular}

Table 4 revealed that almost all organizations have existing constitutions and by-laws duly approved by the members. On the other hand, one of the organizations was still retrieving their filed constitution and by-laws since the previous file could no longer be found. Almost all of the organizations chose their officers by means of election, except the YMA and SYBEE, in which the advisors can appoint officers due to lack of planning and time to hold a meeting. Furthermore, the majority of organizations were not registered with the national confederation and or association. 
Table 5: The Legality of Operation (Past officers)

\begin{tabular}{lcccc}
\hline & Yes & Percentage & No & Percentage \\
\hline Existing constitution and by-laws & 24 & $100 \%$ & 0 & $0 \%$ \\
Approved plan/calendar of activities & 12 & $50 \%$ & 12 & $50 \%$ \\
$\begin{array}{l}\text { Approval of members in by laws } \\
\text { Registration with a national confederation }\end{array}$ & 0 & $0 \%$ & 24 & $100 \%$ \\
and organization & 6 & $25 \%$ & 18 & $75 \%$ \\
Election of officers from members & 24 & $100 \%$ & 0 & $75 \%$ \\
Issuance of special order to advisers & $25 \%$ & 18 & $0 \%$ \\
\hline
\end{tabular}

Table 5 showed that the previous officers of most all of the organizations have almost results with the above present findings in the organization's officers.

Table 6: The Legality of Operation (Advisers)

\begin{tabular}{lcccc}
\hline & Yes & Percentage & No & Percentage \\
\hline $\begin{array}{l}\text { Existing constitution and by- } \\
\text { laws }\end{array}$ & 9 & $38 \%$ & 0 & $0 \%$ \\
$\begin{array}{l}\text { Approved plan/calendar of } \\
\text { activities }\end{array}$ & 6 & $25 \%$ & 3 & $13 \%$ \\
$\begin{array}{l}\text { Approval of members in by } \\
\text { laws }\end{array}$ & 0 & $0 \%$ & 9 & $38 \%$ \\
$\begin{array}{l}\text { Registration with a national } \\
\text { confederation and }\end{array}$ & 2 & $8 \%$ & 7 & $29 \%$ \\
$\begin{array}{l}\text { organization } \\
\text { Election of officers from }\end{array}$ & 3 & $13 \%$ & 6 & $25 \%$ \\
$\begin{array}{l}\text { Issuance of special order to } \\
\text { advisers }\end{array}$ & 9 & $38 \%$ & 0 & $0 \%$ \\
\hline
\end{tabular}

As can be gleaned, Table 6, however, the same with the present and previous officer's results, were the approval of by-laws was not considered important for advisers but will served as a requirement only for renewal.

\section{Awareness of Designation and Function of Officers and Advisers in terms of Internal Financial Control System}

Based on the interview, the majority of the organizations required the signatures of two officers and the adviser. This mean that three signatures were required to complete a particular organization's transaction. According to Brown University Student Activities Office, this scheme will minimize the risk that funds would be used for personal reasons, thus, ensuring that the organization's costs are of a fair and essential nature to support the organization's mission.

However, the result also showed that the organizations have no bank accounts yet. This affirms the result of the latest Financial Inclusion Survey conducted by the Bangko Sentral ng Pilipinas. 
Only one-fourth of all Filipinos own bank accounts that facilitate their financial system and licensed (Lucas, 2018). In terms of budget proposal and approval, the respondents answered that their treasurer prepared the budget, organization adviser, and the President. According to Chen et al. (1998), as cited by Shahrabani (2012), strong evidence suggests that college students may not have a high financial literacy level. The budget is, therefore, an invaluable tool to help prioritize expenditures and allocate capital. Budget preparation and control will help the organization recognize unnecessary spending, respond rapidly to changes in the financial situation, and achieve financial objectives. Through budgets, resources are allocated to projects or events necessary, and if the resources are not enough, organizations can devise income-generating projects to augment their expenditures. It should also be carefully prepared after determining the scheduled activities of the organization for the year. The financial plan may consider the financial goals and probabilities of success and may be revised to reflect changes in the financial goals and probabilities of success (Wiks et al., 2011). However, the treasurer should indeed be the organization's cash custodian; some respondents responded that their adviser had managed their funds. No proper accounting or internal control systems were applied in the organization. They used the collections to buy their organizational needs without proper source documents.

Conversely, one of the key roles of accounting is adjudicating, which means that accounting plays a vital role in the success of entries and organizations and in recognizing errors and failures (Miller and Power, 2017). In addition to the idea of the division of duties, the preparation of vouchers should also be segregated from the officer who approves it. In this report, the preparation of cash vouchers rests with the treasurers, and the approval is normally with the president and/or the adviser. However, some and most answered that their organizations were not using cash vouchers and receipts, which should not be the case since these were important documents to assess the validity of the transaction. According to Siddiqui (2011), cash vouchers are prepared as documentary evidence of cash payments and cash receipts. According to the interview, there are some cases that the elected class president/s and other non-political organization's president collected money but declared it stolen, and some were considered as dropped on the campus.

\section{Practices by the Officers and Advisers in terms of Financial Internal Control System}

Table 7: Budget Proposal Preparation

\begin{tabular}{lccccccccccc}
\hline & \multicolumn{3}{c}{$\begin{array}{c}\text { PRESENT } \\
\text { OFFICERS }\end{array}$} & \multicolumn{3}{c}{$\begin{array}{c}\text { PREVIOUS } \\
\text { OFFICERS }\end{array}$} & \multicolumn{3}{c}{ ADVISERS } \\
\hline & TFS & WM & VI & TFS & WM & VI & TFS & WM & $\begin{array}{r}\text { V I } \\
\text { BUDGET PROPOSAL }\end{array}$ \\
$\begin{array}{l}\text { PREPARATION } \\
\begin{array}{l}\text { 1.Budgets are prepared for the events of } \\
\text { the organization every semester }\end{array}\end{array}$ & 64 & 2.67 & $\mathrm{~S}$ & 68 & 2.83 & $\mathrm{~S}$ & 38 & 4.22 & $\mathrm{~S}$ \\
$\begin{array}{l}\text { 2. Budgets are prepared in accordance with } \\
\text { the action plan of the organization. }\end{array}$ & 84 & 3.50 & $\mathrm{O}$ & 84 & 3.50 & $\mathrm{O}$ & 34 & 3.78 & $\mathrm{O}$ \\
$\begin{array}{l}\text { 3. Budget preparation is participated by all } \\
\text { officers of the organization including } \\
\text { advisers. }\end{array}$ & 92 & 3.83 & $\mathrm{O}$ & 92 & 3.83 & $\mathrm{O}$ & 34 & 3.78 & $\mathrm{O}$
\end{tabular}




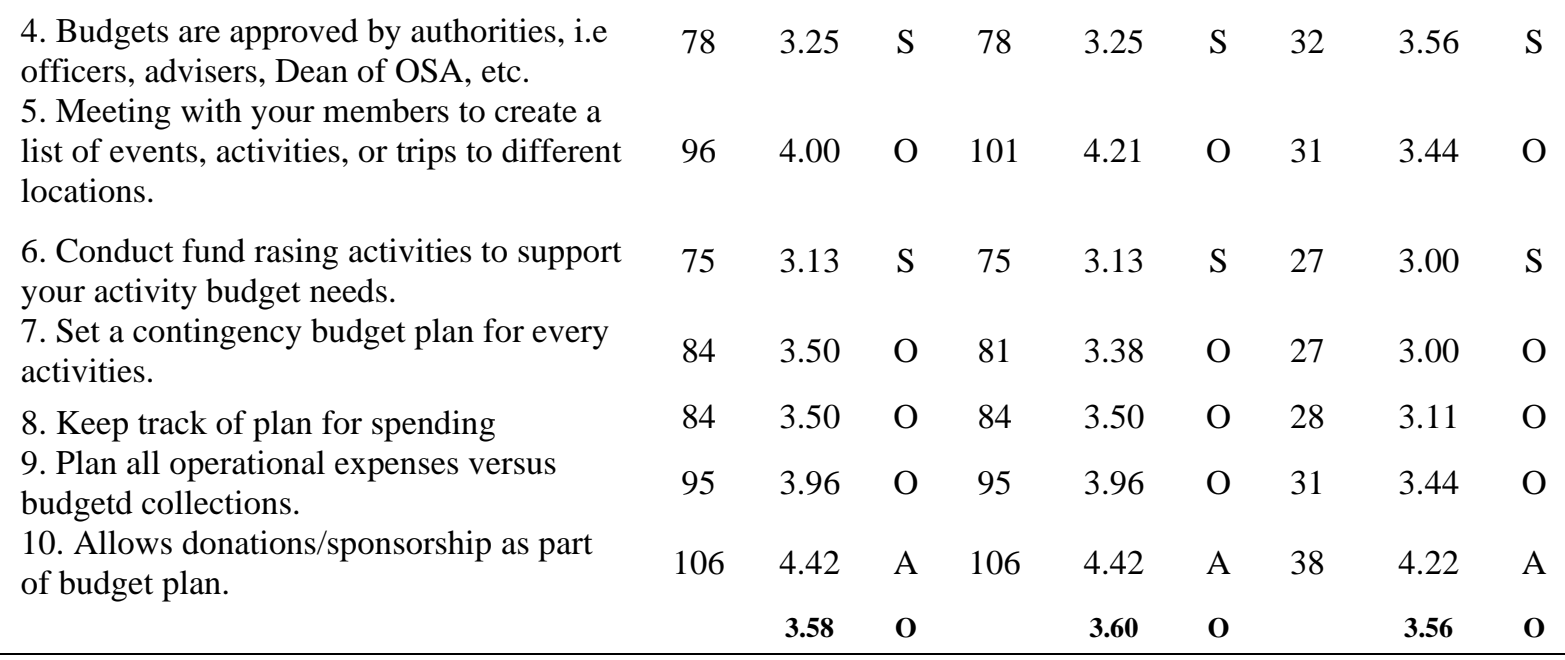

Table 7 shows that the budget proposal preparation was "Often" done by student organizations. A budget is an invaluable tool that helps to plan to spend and allocate resources. Budget preparation and control will help the company recognize unnecessary spending, respond rapidly to changes in the financial situation, and achieve financial objectives. Budget plans should be planned and accepted and serve as a method for comparing budgeted and real disbursements and assessing variance. According to Dropkin et al. (2011), a well-managed nonprofit organization's key economic goal should be to remain solvent, and budgeting is the optimum method for promoting this objective.

\section{Table 8: Cash Receipt Preparation}

\begin{tabular}{|c|c|c|c|c|c|c|c|c|c|}
\hline & \multicolumn{3}{|c|}{ Present } & \multicolumn{3}{|c|}{ Past } & \multicolumn{3}{|c|}{ Advisers } \\
\hline & $\begin{array}{c}\text { Total } \\
\text { Frequ } \\
\text { ency } \\
\text { Score }\end{array}$ & $\begin{array}{l}\text { Weig } \\
\text { hted } \\
\text { Mean }\end{array}$ & $\begin{array}{c}\text { Verbal } \\
\text { Interpre } \\
\text { tation }\end{array}$ & $\begin{array}{c}\text { Total } \\
\text { Frequ } \\
\text { ency } \\
\text { Score }\end{array}$ & $\begin{array}{l}\text { Weig } \\
\text { hted } \\
\text { Mean }\end{array}$ & $\begin{array}{c}\text { Verbal } \\
\text { Interpre } \\
\text { tation }\end{array}$ & $\begin{array}{l}\text { Total } \\
\text { Frequ } \\
\text { ency } \\
\text { Score }\end{array}$ & $\begin{array}{l}\text { Weig } \\
\text { hted } \\
\text { Mean }\end{array}$ & $\begin{array}{c}\text { Verbal } \\
\text { Interpre } \\
\text { tation }\end{array}$ \\
\hline $\begin{array}{l}\text { 1. Remittances } \\
\text { by the collectors } \\
\text { to the treasurers } \\
\text { are done every } \\
\text { day (during the } \\
\text { collection } \\
\text { period) }\end{array}$ & 56 & 2.33 & $\mathrm{R}$ & 68 & 2.83 & $S$ & 38 & 4.22 & $S$ \\
\hline $\begin{array}{l}2 . \text { The } \\
\text { organization } \\
\text { has pre- } \\
\text { numbered } \\
\text { official } \\
\text { receipts. }\end{array}$ & 30 & 1.25 & $\mathrm{~N}$ & 84 & 3.50 & $\mathrm{O}$ & 34 & 3.78 & $\mathrm{O}$ \\
\hline $\begin{array}{l}\text { 3. Cash } \\
\text { collections } \\
\text { are issued } \\
\text { with official } \\
\text { receipts. }\end{array}$ & 32 & 1.33 & $\mathrm{~N}$ & 92 & 3.83 & $\mathrm{O}$ & 34 & 3.78 & $\mathrm{O}$ \\
\hline $\begin{array}{l}\text { 4. Collectors are } \\
\text { authorized } \\
\text { through } \\
\text { resolutions and } \\
\text { other pertinent } \\
\text { documents. }\end{array}$ & 47 & 1.96 & $\mathrm{R}$ & 78 & 3.25 & S & 32 & 3.56 & $S$ \\
\hline
\end{tabular}


5. Remittances are supported by a control sheet or cash 57 2.38 S 101 4.21

31

3.44

$\mathrm{O}$

count sheet.

6. Collections

for the day are deposited intact

within the next

banking day.

7. Funds are kept in a bank or other

financial institution. 8. Petty cash fund is maintained by the organization. 9. Petty cash fund is kept in a safe place by the

1.08

custodian.

10.

Comparison

of actual and

budgetary

expenses is

89

3.71

O

106

4.42

A

38

4.22

A

done.

\subsection{Rarely}

3.60 Often

3.56 Often

As can be seen from Table 8 , remittances by the collection represented by the class to the treasurer were done every day but not in practice. This practice will keep the records updated as well as prevent the risk of loss or theft. In the case of other sections, their collection was not remitted to the Confederation treasurer/s. However, some organizations did not maintain a small cash fund intended to cover expenditures to prevent regular withdrawals from the account. The custodian of the petty cash fund has the authority to make payments from the fund that conforms to prescribed management policies (Kimmel, 2019). Further, organizations did not relate to actual and budgetary expenses. This instrument would guide the next student leaders regarding setting a budget for the next academic year. This would also assess the effectiveness of the budget set forth by the organization. The table also show that organizations spent the amount stated in the budget, evidenced by a cash voucher of the organization duly approved by the president and the adviser in cash disbursements.

Table 9: Cash Disbursementt Preparation

\begin{tabular}{|c|c|c|c|c|c|c|c|c|c|}
\hline & \multicolumn{3}{|c|}{ Present } & \multicolumn{3}{|c|}{ Past } & \multicolumn{3}{|c|}{ Adviser } \\
\hline & $\begin{array}{c}\text { Total } \\
\text { Frequ } \\
\text { ency } \\
\text { Score }\end{array}$ & $\begin{array}{l}\text { Weig } \\
\text { hted } \\
\text { Mean }\end{array}$ & $\begin{array}{l}\text { Verbal } \\
\text { Interpre } \\
\text { tation }\end{array}$ & $\begin{array}{c}\text { Total } \\
\text { Frequ } \\
\text { ency } \\
\text { Score }\end{array}$ & $\begin{array}{l}\text { Weig } \\
\text { hted } \\
\text { Mean }\end{array}$ & $\begin{array}{l}\text { Verbal } \\
\text { Interpre } \\
\text { tation }\end{array}$ & $\begin{array}{c}\text { Total } \\
\text { Frequ } \\
\text { ency } \\
\text { Score }\end{array}$ & $\begin{array}{l}\text { Weig } \\
\text { hted } \\
\text { Mean }\end{array}$ & $\begin{array}{c}\text { Verbal } \\
\text { Interpre } \\
\text { tation }\end{array}$ \\
\hline $\begin{array}{l}1 . \\
\text { Disbursements } \\
\text { are by the } \\
\text { approved } \\
\text { budget. }\end{array}$ & 63 & 2.63 & S & 71 & 2.96 & S & 27 & 3.00 & S \\
\hline
\end{tabular}


2. CDV's are duly approved by the

President of the

organization and adviser.

3.

Disbursements are supported by official receipts and acknowledged by the payee.

4.

Disbursements are supported by resolutions and cash disbursement vouchers.

5. Purchases of tangible assets are supported by canvass from suppliers.

6. The approving authorities approve 6. Disbursements on petty cash funds.

7. The organization has a policy on cash advances and liquidation. 8. Withdrawal slips are prepared once the CDV and resolution were approved.

9. The organization has a policy on cash

$1.08 \quad \mathrm{~N}$

26

1.08

N

29

3.22

S

24

1.00

N

28

1.17

$\mathrm{N}$

9

1.00

$\mathrm{N}$

31

1.29

43

1.79

$\mathrm{N}$

43

1.79

$\mathrm{N}$

9

1.00

$\mathrm{N}$

shortage/overag

e.

10. CDV's are

pre-numbered.

$\begin{array}{lllll}1.00 & \mathrm{~N} & 9 & 1.00 & \mathrm{~N} \\ \mathbf{1 . 7 9} & \mathbf{N} & & \mathbf{1 . 9 6} & \mathbf{R}\end{array}$

Sometimes disbursement is not supported by the student leaders' resolutions showing that it was agreed among the organization's officers. The canvass of supplies and other tangible assets is not common among the organizations and policy on cash advances and liquidation. Besides, CDVs are not pre-numbered, and the policy on cash shortages or overage is not defined. Prenumbering helps avoid transactions from being recorded more than once or, conversely, from not being recorded at all (Kimmel, 2019. It is noted that the primary goal of internal controls 
on cash disbursements is to ensure that cash is properly disbursed only after proper management authorization, for legitimate business reasons, and that all disbursements are properly registered. If management routinely reviews transactions then the potential for fraudulent activities to be uncovered serves as a deterrent for fraudulent behavior (Brown, 2011). Moreover, as far as record-keeping is concerned (Table 10), financial statements were always complied with by organizations at least once a semester based on their cash register and other related reporting documents. The financial statement aims to convey an understanding and content of an organization's financial data (Rao, 2011). On the other hand, the inventory of unused accounting forms has sometimes been carried out by the officers, which means that the organization's materials and other assets have not been closely monitored.

Table 10: Record Keeping / Bookkeeping

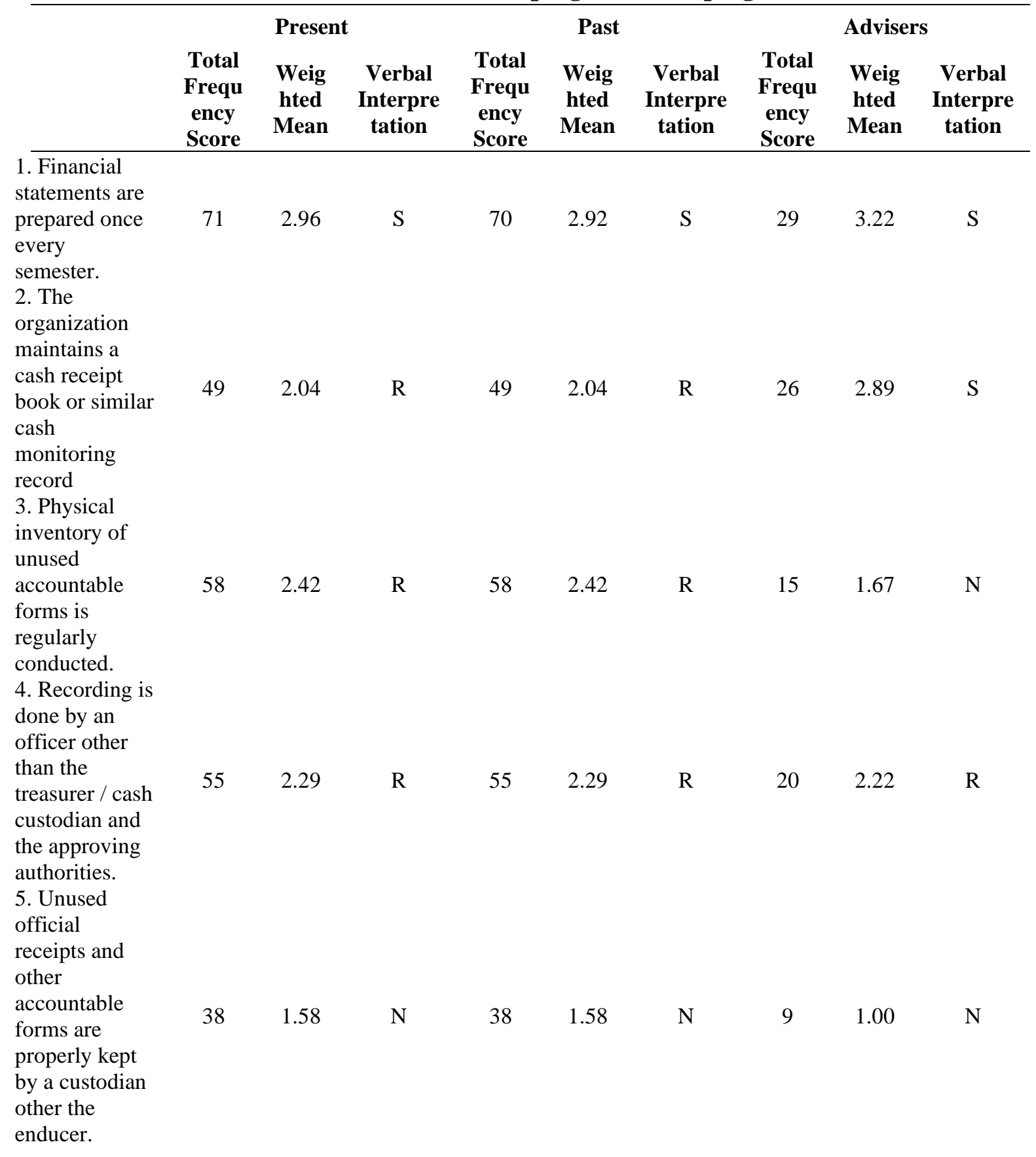


6. Audited and approved

financial

statements are

reported to the

$\begin{array}{lll}47 & 1.96 \quad \mathrm{R}\end{array}$

49

2.04

R

9

1.00

$\mathrm{R}$

members of

the

organization.

7. Cash

collections and

disbursements

are regularly

recorded in the

$2.46 \quad \mathrm{~S}$

59

2.46

S

11

1.22

N

cash receipt

book.

8. Bank

reconciliations are made by

the treasurer

and audited by

the auditor.

9. Physiscal

counting of

assets,

inventories,

cash and others

$2.08 \quad \mathrm{R}$

53

2.21

R

20

2.22

$\mathrm{R}$

accounts.

10.

Reconciliation of Recievables, Payables,

Investories and

$\begin{array}{lll}34 & 1.42 \quad \mathrm{~N}\end{array}$

40

1.67

$\mathrm{N}$

15

1.67

$\mathrm{N}$

other assets.

Prepared

schedules.

2.02 R

$2.06 \quad R$

1.81

$\mathbf{R}$

Recording day-to-day transactions and operations of student organization is important in achieving proper internal control system. In pursuit of organizational goals in terms of accurate financial statements, successful and productive activities, administratorsand board of directors of companies have recourse to the establishment of internal control mechanisms to ensure effective performance Crawford (2011). It is assumed that properly structured and implemented internal control mechanisms would usually lead to improved financial reporting practices and credible report that enhances the transparency management role of an organization (Doyle, et al. 2007).

Problems Encountered by the Officers and Advisers in terms of Financial Internal Control System

Table 11: Problems Encountered in terms of Internal Control System

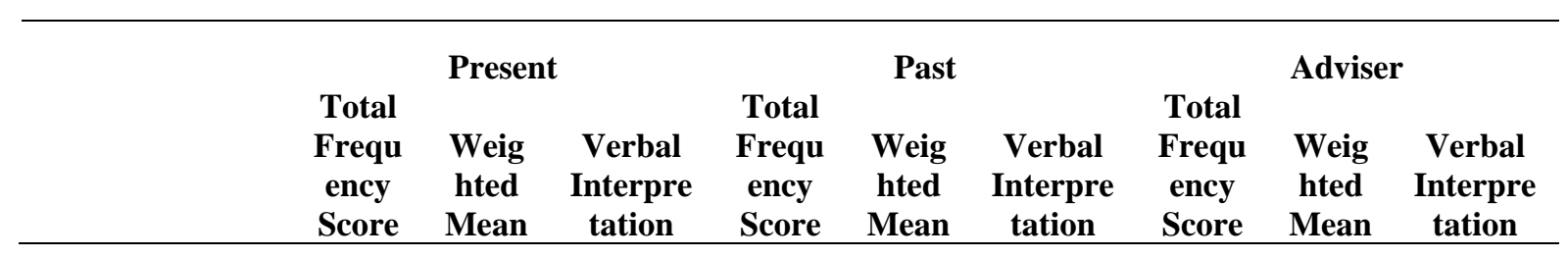




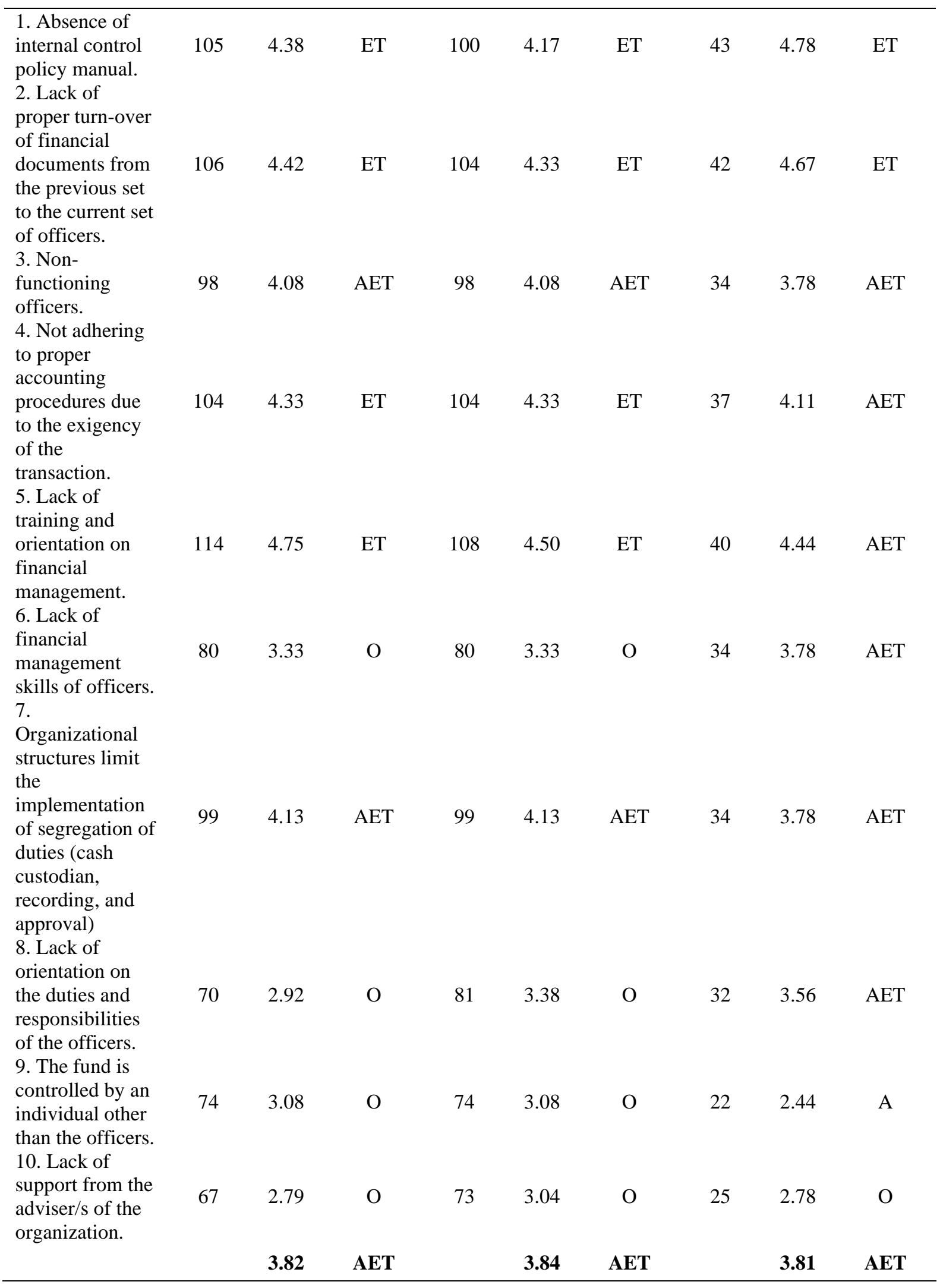

Table 11 revealed that most "Almost Every Time" political and non-political student organizations do not have an internal control management system framework and a manual as a basis for handling their funds using that financial system. Cambridge Dictionary (n.d) described the policy as a collection of ideas or strategies of what to do in specific circumstances 
that have been formally decided upon by a group of people, a business association, a government, or a political party. Officers hold an elected position; therefore, they were subject to certain errands. Those who do not comply with the minimum standards of conduct will be individually responsible for restoring the scheme's damages, because errors and fraud can and do occur, it is vital to have protections to ensure that officers in the student organization can appropriately carry out their fiduciary duties. One way to do this is to introduce appropriate internal control over financial statements, as set out in the Internal Control Policy Manual. According to Zamzani et al., 2018, as mentioned by Ardhiani et al. (2020), the cash out process's internal security can avoid mistakes or theft such that cash outlays can be deemed to be successful. Accounting information on cash spending will be easier if it has appropriate and structured monitoring procedures. Internal controls are a framework, of policies, procedures, analysis and strategies put in place by the organization to prevent fraud, ensure the veracity and reliability of financial and accounting information and to protect the organization's financial assets, including but not limited to its cash flow (Schaeffer, 2014) Segregation of duties is a form of internal control.

The lack of turn-over of financial records from the previous group of officers was another issue the organizations faced. Too often, the organization leaders commit themselves to effectively leading their groups for the academic school year and, at the end of their term, leave. When this occurs, not all information on the lessons learned in the previous year is passed on to new officers, thereby slowing down their progress. Without taking the time to successfully transition new officers, organizations are missing the ability to maintain the momentum they built in the previous year. A time that could be used to drive the organization forward and reach new goals is focused on catching up. Non-functioning officers were among the challenges the organization had faced, thereby requiring officers to step into another's shoes. This may conflict with the concept of division of duties when example, the President on the approval authority prepares a cash voucher or a financial statement. Few officers have found that their funds were managed by persons other than officers, which should not be the case because their capacity to act as officers is limited, not to mention that the funds should be in possession of students, not with someone else.

\section{Conclusion \& Recommendation}

The lack of specific manual and expertise in the accounting and internal control system had resulted in an organization with no clear direction of duties and responsibilities. This resulted in one officer performing the duties that are to be performed by other officers in the organization. Most of the organizations whose funds have not yet been deposited in a bank or other financial institution and others are in the hands of individual and officials who delineate the freedom of student organization in carrying out their function, as well as partially overcoming the goal of providing student organizations at the NEUST in general and San Isidro Campus in particular. As far as accounting activities are concerned, the organization typically carry out their work daily. However, some variations should be stressed for a stronger financial management system, such as creating a revolving fund and comparing real and budgetary expenditure. Organizational disbursement procedures are not yet in place. They need to be changed, particularly on the pre-counting of Cash Disbursement Vouchers (CDV) and the policy on cash advance, shortage, and overage.

In this conclusion, the researchers recommended holding annual training for the leader's program to manage its finances. In the same vein, a group of experts in this field may drop a manual of operation in financial and internal control systems for the political and non-political organizations of the NEUST-San Isidro Campus. The officers and advisers of different 
organizations together with the Office of the Students Organizations, Activities and Development (OSOAD), and the Office of the Student Affairs (OSA) must be the responsible offices for submitting the well prepared and audited financial statements of the organization. The audited financial statements should be posted on the organization's transparency board every after the event is conducted and facilitated by the organization.

\section{References}

[1] Ardhiani, M.R. et al. (2020). Analysis of cash expenditure effectiveness through the accounting information system of P.T. Telkom Indonesia Regional Division V. International Journal of Economics, Business and Accounting Research (IJEBAR) Peer Reviewed - International Journal, 4(3).

[2] Brown, M. S. (2011, July). The Dishonest "Trusted Bookkeeper" Signs of Internal Fraud, How to Respond and Investigte. Valuation and Litigation Advisor

[3] Cambridge Dictionary (n.d.) Policy. Cambridge University Press, 2020.

[4] Crawford, R. L., \& Weirich, T. R. (2011). Fraud guidance for corporate counsel reviewing financial statements and reports. Jourrnal of financial crime, 18 (4), 347-360.

[5] Doyle, J., Ge, W., and S. McVay, S. (2007), Determinants of weaknesses in internal control over financial reporting. Working paper, Utah State University of Washington, and New York University.

[6] Dropkin, M. et al. (2011). The budget-building book for nonprofits: A step-by-step guide for managers and boards. San Francisco, CA. John Wiley \& Sons, Inc.

[7] Jongbloed B., Vossensteyn H., van Vught F., Westerheijden D.F. (2018). Transparency in higher education: The emergence of a new perspective on higher education governance. In: Curaj A., Deca L., Pricopie R. (eds) European Higher Education Area: The Impact of Past and Future Policies. Springer, Cham. https://doi.org/10.1007/978-3-319-77407-7_27

[8] Khandpekar \& Neeta ( 2016). The role of NGOs in education system episteme. An Online Interdisciplinary, Multidisciplinary \& Multi-cultural Journal, Bharat 5(30.

[9] Kimmel, P. et al. (2019). Accounting: Tools for business decision making. United States of America (USA): John Wiley \& Sons, Inc. ISBN: 9780470377857

${ }^{[10]}$ London School of Business and Finance, 2018, retrieved from https://www.lsbf.org.uk/blog/news/importance-of-financial-management/117410

${ }^{[11]}$ Longtoy, Perlas, et al. (2018). Sustainable financial management practices: Its impact on stakeholders. $\quad$ Retrieved from https://www.academia.edu/35990845/Sustainable_Financial_Management_Practices_Its_Im pact_To_Stakeholders_Docx

${ }^{[12]}$ Lucas, D. (2018). The majority of Filipinos still have no bank accounts, says Bangko Sentral. Philippine Daily Inquirer. Retrieved from https://business.inquirer.net/253863/majorityfilipinos-still-no-bank-accounts-says-bangko-sentral

[13] Miller, P., and Power, M. (2017). Accounting, organizing, and economizing: Connecting accounting Research and organization theory. Academy of Management Annals, 7(1).

[14] Rafindadi, A.A. \& Olanrewaju, Z. U. (2019). Impact of internal control system on the financial accountability of non-governmental organizations in Nigeria: Evidence from the structural equation modeling. International Review of Management and Marketing Econ Journals, 9(3), 49-63.

${ }^{[15]}$ Rao, P. (2011). Financial Statement Analysis and Reporting. New Delhi: PHI Learning Private Limited.

[16] Schaeffer, M. S. (2014). Internal Controls in Accounts Payable. Crystallus, Inc.

[17] Shahrabani, S. (2012). The effect of financial literacy and emotions on intent to control personal budget: A study among Israeli College Students. International Journal of Economics \& Finance, 4(9). 


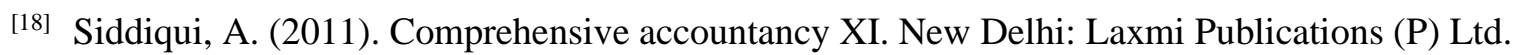

[19] Taylor, L. (2019). The role of non-governmental organizations in global education: A case study on Sub-Saharan Africa. Honors Theses. 1154. https://egrove.olemiss.edu/hon_thesis/1154

[20] Wiks, BW et al. (2011). Systems and methods for the financial plan are benchmarking. U.S. Patent No. 7895102B1. United States. United Services Automobile Association USAA. 